\title{
TEKTONOSTRATIGRAFI DAN SIKUEN STRATIGRAFI ENDAPAN LISU BLOK DUYUNG, CEKUNGAN NATUNA BARAT
}

\author{
ANY A. RACHMAD, DJUHAENI, PRIHADI SUMINTADIREDJA \\ Program Studi Teknik Geologi, Fakultas Ilmu dan Teknologi Kebumian, Institut Teknologi Bandung (ITB), \\ Jl. Ganesha No.10 Bandung, Jawa Barat, Indonesia, 40132, Email: ariyani.rachmad@gmail.com
}

\begin{abstract}
Sari - Blok Duyung berlokasi di lepas pantai Natuna dan secara geologis merupakan bagian dari Cekungan Natuna Barat. Area penelitian merupakan area Seismik 3D bagian dari Blok Duyung dengan luas sekitar 412 kilometer persegi. Penelitian ini bertujuan untuk mengetahui stratigrafi endapan lisu di Blok Duyung dengan memahami penyebaran dan fasies seismik pada interval kedalaman lisu. Peta fasies seismik dibuat berdasarkan analisis seismik geomorfologi menggunakan metoda sayatan strata (stratal slice) dengan menampilkan atribut seismik CWT (Continuous Wavelet Transform).
\end{abstract}

Berdasarkan korelasi litostratigrafi dan informasi Sumur AA-1X dan Sumur Forel-2, endapan lisu berada dalam lingkungan pengendapan supratidal, air tawar yang didominasi lakustrin. Berdasarkan analisis seismik geomorfologi dengan sayatan strata, di daerah penelitian dijumpai tiga sistem pengendapan di area lisu, yaitu: deltaik fluvial, lakustrin dangkal dan lakustrin dalam.

Secara tektonostratigrafi, endapan lisu di daerah penelitian dapat dibagi dalam 4 fase, yaitu: Lisu Awal (Early Rift), Lisu Tengah (Middle Rift), Lisu Akhir (Late Rift) dan Pasca-lisu Awal (Early Post-rift). Batas antara keempat fase tektonostratigrafi ditentukan berdasarkan analisis ekspresi seismik. Berdasarkan analisis seismik-sikuen stratigrafi, area lisu dapat dibagi menjadi 3 paket sikuen, yaitu: Sikuen-1 (Interval SB0-SB1), Sikuen-2 (Interval SB1-SB2) dan Sikuen-3 (Interval SB2-SB3). Secara umum, batas tektonostratigrafi dan batas sikuen stratigrafi di area penelitian relatif berimpit, namun semakin ke arah bonding fault-rift, perbedaan batas tersebut semakin terlihat.

Kata Kunci: lisu, rift, tektonostratigrafi, seismik-sikuen stratigrafi, Natuna Barat.

\begin{abstract}
Duyung Block is located in the Natuna Sea and geologically is the part of West Natuna Basin. The area of research is the 3D seismic area, part of Duyung Block, covering approximately 412 square kilometers. This study aims to determine the stratigraphy of syn-rift deposition in Duyung Block to understand the distribution and seismic facies at the depth interval of syn-rift. Seismic facies map is generated based on seismic geomorphology analysis using stratal slice method with displaying CWT (Continuous Wavelet Transform) seismic attribute.
\end{abstract}

Based on lithostratigraphy correlation and the information from AA- $1 X$ and Forel-2 wells, syn-rift sediment were deposited within a supratidal, fresh water, predominantly lacustrine. The analysis of seismic geomorphology with stratal slices in the area of research encountered three depositional systems in the area of syn-rift, i.e., fluvial deltaic, shallow lacustrine and deep lacustrine.

Rift depositional system in the study area can be divided into four tectonostratigraphy phases, i.e., Early Rift, Middle Rift, Late Rift and Early Post-rift. The boundary between tectonostratigraphy phases is determined from the analysis of seismic expression. Based on the analysis of seismic-sequence stratigraphy, syn-rift depositional system can be divided into 3 sequence packages, i.e., Sequence-1 (interval SBO-SB1), Sequence-2 (interval SB1-SB2) and Sequence-3 (interval SB2-SB3). Generally in the area of research, the tectonostratigraphy boundaries are relatively coincide with the sequence boundaries, but toward bonding fault-rift, the difference between those two are increasingly visible.

Keywords: syn-rift, tectonostratigraphy, seismic sequence stratigraphy, West Natuna.

\section{PENDAHULUAN}

Potensi hidrokarbon Cekungan Natuna Barat terdapat pada area lisu yang relatif belum tereksplorasi (Sladen, 1997; Maynard dkk.,
2002 dalam Burton dan Wood, 2010). Pengetahuan mengenai sistem petroleum di area lisu masih sangat terbatas, sementara sedikitnya sumur-sumur pengeboran di 
cekungan ini yang mencapai kedalaman lisu akan meningkatkan resiko eksplorasi. Selain itu, lingkungan pengendapan fluvial, deltaik dan lakustrin di area lisu menghasilkan diskontinuitas reflektor seismik yang membuat interpretasi kemenerusan horizon di area tersebut menjadi tantangan tersendiri. Penelitian ini bertujuan untuk mengetahui stratigrafi endapan lisu di Blok Duyung dengan memahami penyebaran dan fasies seismik pada interval kedalaman lisu.

Endapan lisu pada Cekungan Natuna Barat diketahui pada umumnya merupakan lingkungan supratidal hingga lakustrin dalam, karena itu, tidak hanya tektonostratigrafi, namun seismik-sikuen stratigrafi dapat diterapkan di daerah penelitian. Pada penelitian ini, proses dan sedimentasi yang terjadi pada tiap-tiap sub cekungan di Cekungan Natuna Barat saat pelisuan (rifting) diasumsikan sama dan daerah penelitian merupakan bagian dari setengah terban dari salah satu sub cekungan tersebut.

\section{TATANAN GEOLOGI DAERAH PENELITIAN}

Blok Duyung meliputi area seluas $4.640 \mathrm{~km}^{2}$ dan keseluruhan area berlokasi di lepas pantai Natuna dengan kedalaman air berkisar antara 60-100 m. Secara geologis, Blok Duyung merupakan bagian dari Cekungan Natuna Barat. Cekungan tersebut di bagian utara dibatasi oleh Khorat Swell yang merupakan tinggian batuan dasar (basement high) monoklin dengan kemiringan arah selatan. Di bagian selatan dibatasi oleh Paparan Sunda dan di bagian timur oleh Busur Natuna. Di bagian barat laut terbuka ke arah Cekungan Malay sementara di bagian barat daya terbuka ke arah Cekungan Penyu. Di cekungan ini dijumpai beberapa elemen struktur utama yang dapat dikenali, yaitu: Terban Anoa, Terban South Kakap, Tinggian Nothern Central, Tinggian Southern Central dan Terban Anambas (Gambar 1) (Murti dkk., 2015) dengan orientasi struktur utama berarah barat daya-timur laut dan barat laut-tenggara (Wongsosantiko dan Wirojudo, 1984 dalam Murti dkk., 2015) termasuk beberapa sesar terpilin (wrench fault) besar berarah barat laut-tenggara.

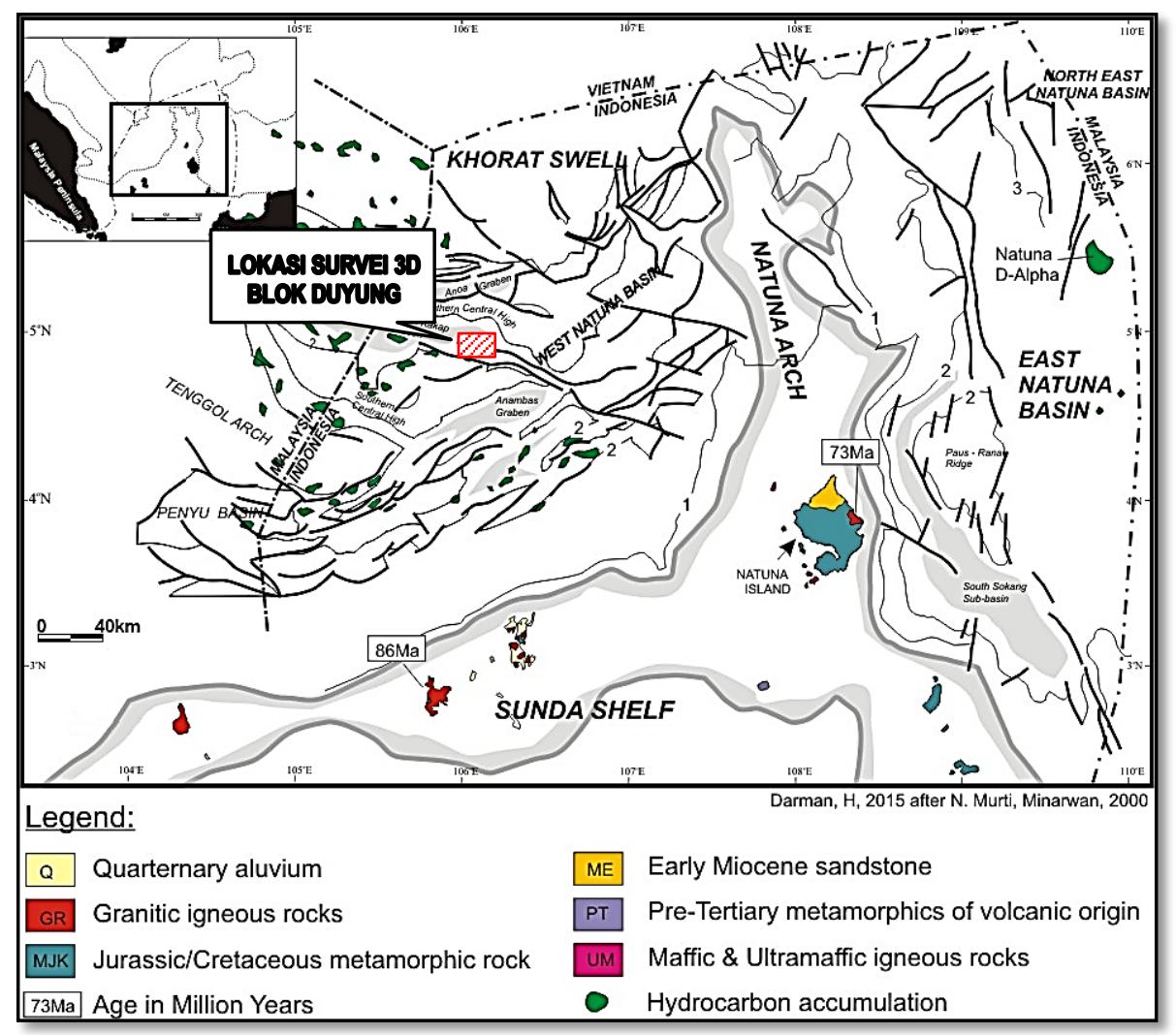

Gambar 1. Elemen struktur Cekungan Natuna Barat (Murti dkk.,2015). 
Cekungan Natuna Barat diklasifikasikan oleh Daines, 1985 dalam Murti dkk., 2015 sebagai cekungan gagal lisu dalam benua (intracontinental failed rift basin). Gagal lisu ini terjadi akibat penghentian subduksi Lempeng Pasifik ke arah utara terhadap Lempeng Eurasia pada kala Eosen. Penghentian ini diikuti oleh pelisuan yang membuka Laut Cina Selatan pada Oligosen Awal-Tengah. Perubahan pergerakan Lempeng Pasifik ini menghentikan subduksi sepanjang garis dari barat daya Kalimantan melalui timur Natuna hingga lepas pantai Vietnam dan berubah menjadi sesar geser (strike-slip fault) (Daly dkk., 1991 dalam Murti dkk., 2015).

Kerangka stratigrafi di Cekungan Natuna Barat dibagi menjadi empat megasikuen tektonostratigrafi utama, yaitu: Lisu (Syn-rift) yang menghasilkan sedimentasi Formasi Lama, Benua dan Lower Gabus; Pasca-lisu (Post-rift) yang menghasilkan sedimentasi Formasi Upper Gabus dan Keras; Sin-inversi (Syn-inversion) menghasilkan sedimentasi Formasi Barat dan Arang serta Pasca-inversi (Post-inversion) menghasilkan sedimentasi Formasi Muda (BPPKA, 1994). Megasikuen tektonostratigrafi pada penelitian ini disebut sebagai fase tektonostratigrafi.

Yang mendasari tatanan stratigrafi di Cekungan Natuna Barat adalah batuan dasar Zaman Kapur (Cretaceous) yang terdiri dari batuan beku asam intrusif seperti diorit kuarsa, granit, filit, sekis klorit, genes dan amfibolit (Murti dkk., 2015). Formasi Lama berumur dari Eosen Akhir (?) hingga Oligosen Awal, dijumpai di atas batuan dasar, terutama terdiri dari batupasir fluvio-deltaik, fluvial dan kipas aluvial. Formasi Benua secara selaras berada di atas Formasi Lama. Formasi Benua merupakan serpih yang diinterpretasikan sebagai endapan lakustrin. Di atas Formasi Benua diendapkan Formasi Lower Gabus berupa perselingan batupasir dan serpih. Batupasir berukuran halus hingga sedang dengan puing tanaman, biasanya tebal, membongkah atau menghalus ke atas dan umumnya terlihat masif. Sikuen ini diinterpretasikan sebagai lingkungan fluvio-deltaik dan fluvial serta berdasarkan polinomorf, berumur Oligosen (Murti dkk., 2015).

\section{DATA DAN METODOLOGI}

\subsection{Data}

Lokasi penelitian adalah area seismik 3D yang terletak di bagian paling utara Blok Duyung. Data yang digunakan dalam penelitian ini (Gambar 2), meliputi:

- Seismik 3D seluas $412 \mathrm{~km}^{2}$ yang di akuisisi pada tahun 2009.

- Duapuluh (20) data seismik 2D yang digunakan untuk mengikat lapisan pemarkah yang terdapat pada data sumur dan mengidentifikasi kemenerusan pemarkah tersebut hingga area seismik 3D.

- Tiga (3) data sumur bor di sekitar area penelitian, yaitu: Cumi-cumi-1 (CC-1), AA-1X dan Forel-2. Sumur AA-1X dan Forel-2 dilewati oleh penampang seismik 2D. Beberapa perusahaan yang memiliki blok konsesi di Cekungan Natuna Barat mengembangkan beberapa kolom stratigrafi dengan tata penamaan yang berbeda-beda, karena itu Sumur CC-1, walaupun tidak dilewati penampang seismik 2D, tetap digunakan sebagai pembanding tata penamaan formasi.

- Data checkshot Sumur CC-1, AA-1X dan Forel-2.

\subsection{Metodologi}

Penelitian ini dilakukan dalam 3 tahap utama, yaitu: analisis data sumur, analisis data seismik 2D dan 3D serta analisis seismik geomorfologi dengan sayatan strata (stratal slice).

\subsubsection{Analisis data sumur}

Korelasi litostratigrafi dilakukan untuk mengidentifikasi kesamaan paket formasi yang berkembang di daerah penelitian (Gambar 3). Mengingat tata penamaan formasi pada masing-masing sumur yang digunakan pada penelitian ini berbeda-beda serta jarak antara sumur-sumur tersebut lebih dari $40 \mathrm{~km}$, maka korelasi litostratigrafi lebih ditujukan untuk mengidentifikasi kesamaan umur. Pada penelitian ini digunakan tata penamaan yang dikeluarkan oleh BPPKA Pertamina tahun 1994 yang diwakili oleh Sumur AA-1X (Gambar 4). 


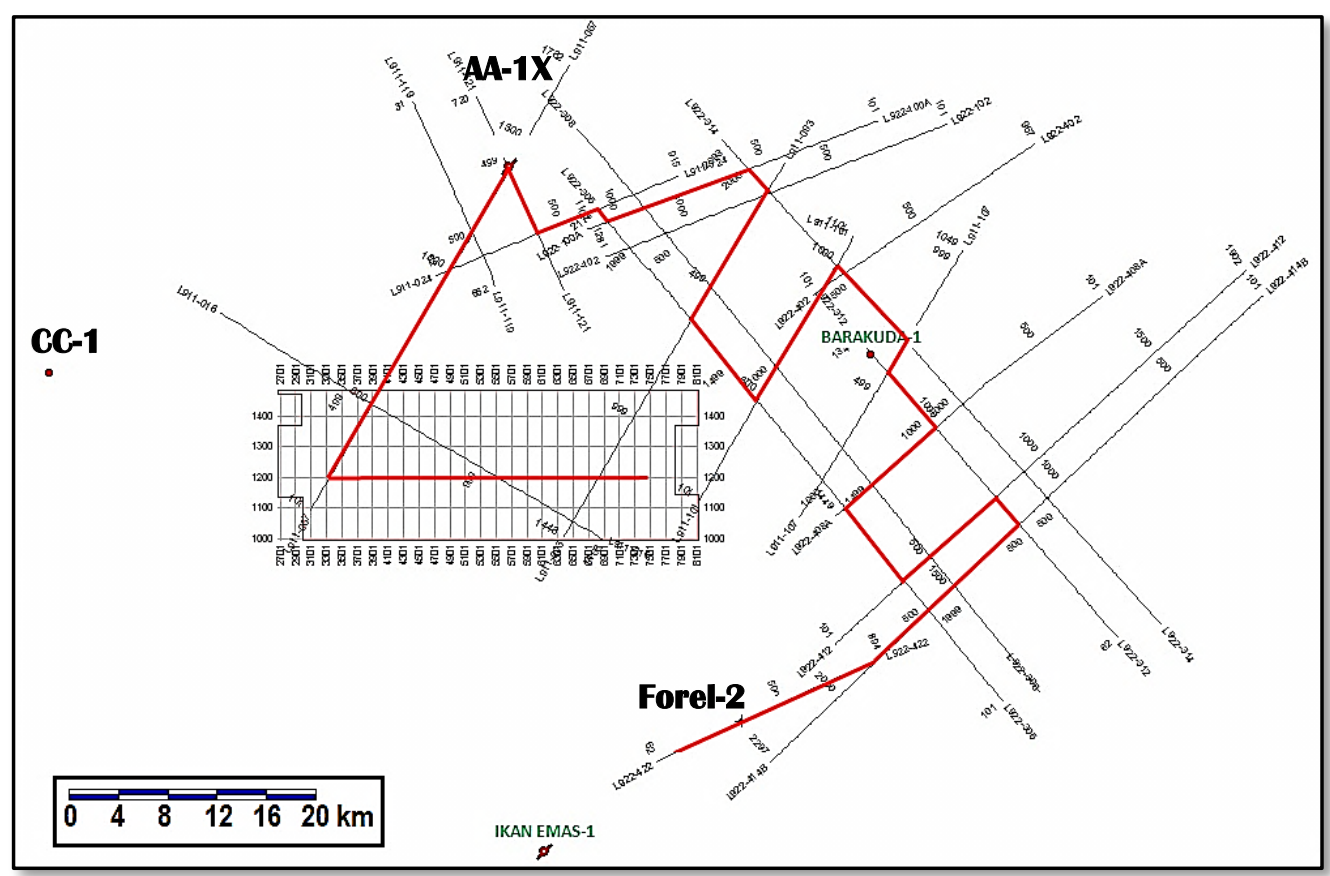

Gambar 2. Data yang digunakan dalam penelitian. Lintasan dengan garis merah merupakan penampang geoseismik untuk mengikat data sumur dengan data seismik 2D-3D.

Identifikasi interval kedalaman lisu dilakukan dengan menggunakan informasi litostratigrafi Sumur AA-1X dan Forel-2 serta data geologi regional. Fase pelisuan di Cekungan Natuna Barat terjadi pada Oligosen Awal-Oligosen Tengah dan menghasilkan sedimentasi Formasi Lama, Benua dan Lower Gabus (Daly dkk., 1991 dalam Murti dkk., 2015). Data biostratigrafi Sumur AA-1X (Robertson Utama Indonesia, 1993) dan Sumur Forel-2 (Continental Oil, 1986) mengindikasikan bahwa endapan lisu berada dalam lingkungan pengendapan supratidal, air tawar yang didominasi lakustrin.

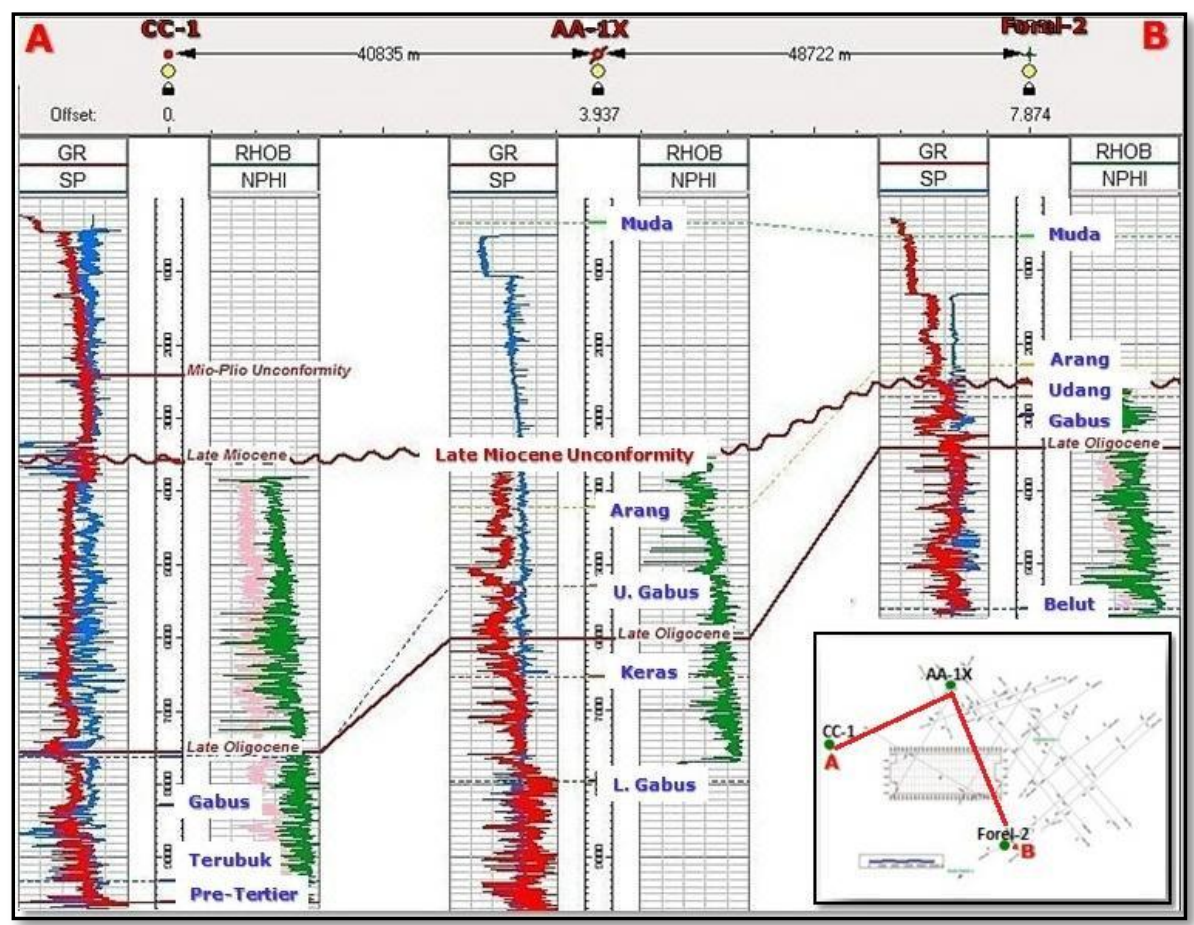

Gambar 3. Litostratigrafi Sumur CC-1, AA-1X dan Forel-2 dengan perbedaan tata penamaan. 


\subsubsection{Analisis data seismik}

Sumur AA-1X yang berjarak sekitar $18 \mathrm{~km}$ dari ujung utara area seismik 3D diikatkan pada penampang seismik 2D, L911-067, kemudian data top formasi pada Sumur AA-1X diinterpretasi kemenerusannya hingga area Seismik 3D. Berdasarkan Sumur AA-1X, Ketidakselarasan Miosen Akhir diinterpretasikan sebagai horizon Top Inversi (Top Inversion) yang merupakan batas antara fase sin-inversi dan pasca-inversi. Horizon Barat yang berumur Oligosen Akhir diinterpretasikan sebagai horizon Top Pasca-lisu (Top Post-rift), yang merupakan batas antara fase pasca-lisu dan sin-inversi.

Interval kedalaman lisu, yang menjadi fokus penelitian ini, pada penampang seismik memiliki bentuk geometri khas berupa setengah terban dengan konfigurasi internal divergen yang dikontrol oleh satu normal bonding-fault pelisuan. Sedimentasi ke arah bonding-fault semakin menebal yang mengindikasikan bahwa sistem pengendapan dikontrol oleh subsiden akibat pelisuan. Posisi bonding-fault diinterpretasikan berada sekitar 15-20 km arah tenggara dari area penelitian.

Batas bawah megasikuen lisu diidentifikasi berdasarkan Top Batuan Dasar (Basement) berumur Pra-Tersier, ditandai dengan reflektor seismik kuat yang menerus tepat berada di atas seismik reflektor chaotic yang menunjukkan indikasi ketidakselarasan nonconformity. Di atas paket lisu terlihat paket geometri strata horizon yang relatif paralel dengan reflektor seismik kuat yang menerus. Hal ini mengindikasikan bahwa paket tersebut sudah merupakan bagian dari megasikuen pasca-lisu yang terbentuk pada masa tektonik tenang dengan sistem pengendapan tidak lagi dipengaruhi oleh subsiden, sehingga batas antara lisu dan pasca-lisu, yaitu horizon Top Lisu (Top Syn-rift) dapat didentifikasi.

Berdasarkan analisis geometri paket seismik serta analisis horizon seismik, evolusi tektonostratigrafi regional yang membagi sistem pengendapan di Cekungan Natuna
Barat menjadi 4 (empat) megasikuen, yaitu Lisu (syn-rift), Pasca-lisu (post-rift), Sin-inversi (syn-inversion) dan Pasca-inversi (post-inversion) (BPPKA, 1994) dapat diidentifikasi di area penelitian. (Gambar 5).

\subsubsection{Analisis seismik geomorfologi dengan sayatan strata (stratal slice)}

Heterogenitas fluvial, deltaik dan lakustrin serta perubahan ketebalan sedimentasi pada endapan lisu di Blok Duyung, Cekungan Natuna Barat membuat reflektor seismik umumnya menjadi tidak kontinu sehingga interpretasi horizon seismik secara konvensional akan lebih memakan banyak waktu. Metoda sayatan strata (stratal slice) dapat memberikan informasi stratigrafi yang konsisten dan gambaran seismik geomorfologi secara lebih cepat dan lebih baik. Stratal slice menampilkan atribut seismik dan perkiraan bentuk pengendapan atau permukaan waktu geologi dengan menggunakan horizon kunci (event) yang berada di atas atau di bawah interval yang diinginkan (Zeng dkk., 2001 dalam Burton dan Wood, 2010). Masing-masing stratal slice menampilkan dominan fasies, namun dapat pula terjadi dua fasies secara luas terlihat dalam satu slice, seperti delta yang berdekatan dengan fasies lakustrin (Burton dan Wood, 2010).

Atribut seismik yang digunakan adalah CWT (Continuous Wavelet Transform). CWT merupakan salah satu metoda komputasi dekomposisi spektral pada domain waktu-frekuensi. Dekomposisi ini ditujukan untuk mengidentifikasi tanggapan frekuensi terhadap lapisan tipis, mengingat data seismik memiliki variasi frekuensi dalam waktu (Sinha dkk., 2005). Kelebihan CWT adalah dapat dilakukan tanpa memerlukan identifikasi jendela frekuensi tertentu karena jendela frekuensi dapat ditentukan dari wavelet seismik sehingga penggunaan atribut ini dirasa cukup bila hanya untuk mendapatkan gambaran umum tanggapan frekuensi terhadap kondisi strata yang akan diidentifikasi. 


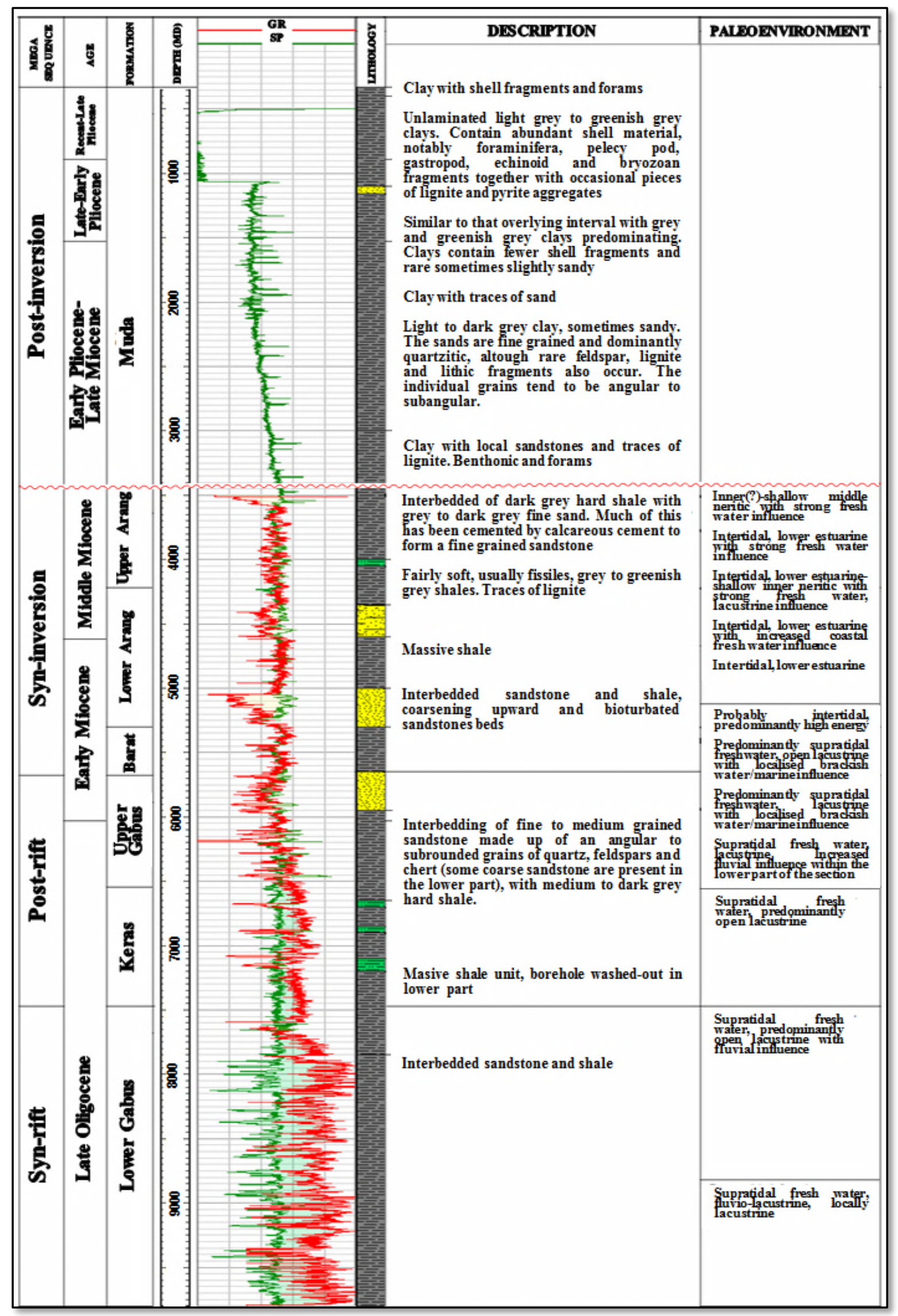

Gambar 4. Kronostratigrafi Blok Duyung berdasarkan Sumur AA-1X (Robertson Utama Indonesia, 1993). 


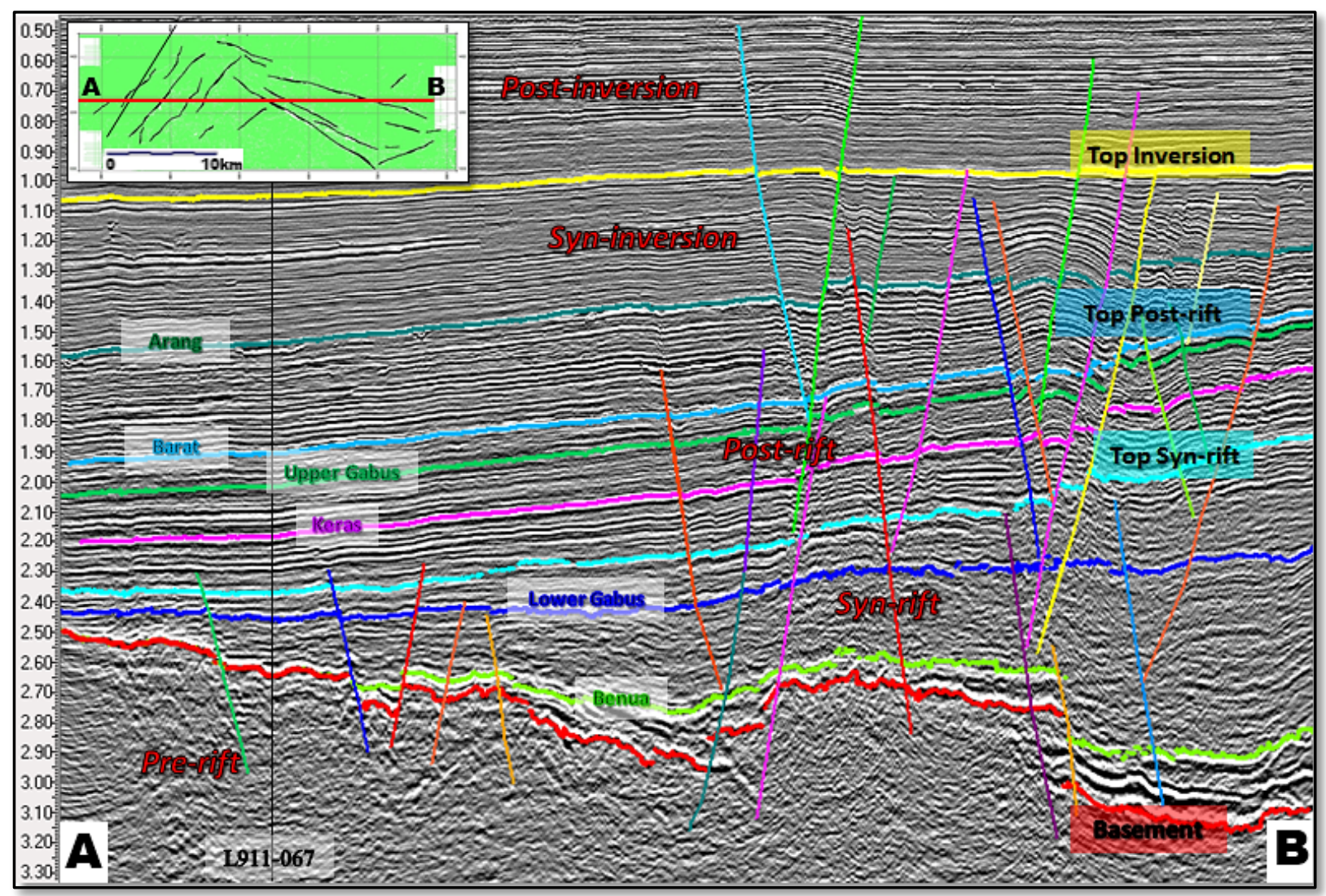

Gambar 5. Evolusi tektonostratigrafi Cekungan Natuna Barat pada Penampang A-B.

Penelitian ini menggunakan piranti lunak SMT Kingdom 2015. Prosedur yang dilakukan dalam analisis stratal slices adalah dengan melakukan identifikasi awal interval paket-paket seismik yang akan diteliti untuk mendapatkan amplitudo seismik yang diduga berasosiasi dengan suatu bentukan stratigrafi tertentu. Pada saat penggunaan metoda ini, harus juga memperhatikan perubahan ketebalan interval paket seismik karena horizon kunci belum tentu memiliki kontinuitas kemiringan yang sama dengan strata target.

Analisis geomorfologi dapat dilakukan dengan cara membuat sayatan horizon (horizon slicing) atau sayatan strata (stratal slicing) dengan cara mendatumkan (flattened) interval yang akan diidentifikasi pada horizon kunci kemudian dibuat ekstraksi amplitudo dari sayatan TWT (time slices) yang paralel terhadap horizon kunci (Posamentier dkk., 2005). Ektraksi amplitudo yang ditampilkan pada peta dasar (basemap) dalam penelitian ini adalah atribut $C W T$.
Berdasarkan analisis stratal slices, dijumpai tiga sistem pengendapan di area lisu Blok Duyung, Cekungan Natuna Barat, yaitu: deltaik fluvial, lakustrin dangkal dan lakustrin dalam. Hal tersebut didukung oleh data biostratigrafi Sumur AA-1X (Robertson Utama Indonesia, 1993) dan Sumur Forel-2 (Continental Oil, 1986) yang mengindikasikan bahwa endapan lisu berada dalam lingkungan pengendapan supratidal, air tawar yang didominasi lakustrin. Konfigurasi internal reflektor seismik pada sistem deltaik fluvial menunjukkan amplitudo rendah-bervariasi dan diskontinu. Amplitudo seismik pada sistem lakustrin diidentifikasi tidak berbentuk dan relatif homogen pada sayatan strata CWT. Kontinuitas dan homogenitas amplitudo lakustrin diinterpretasikan mewakili endapan berbutir halus (Sladen, 1997; Maynard dkk., 2002 dalam Burton dan Wood, 2010). Lakustrin dangkal memiliki amplitudo yang lebih rendah daripada lakustrin dalam (Burton dan Wood, 2010). 


\section{TEKTONOSTRATIGRAFI ENDAPAN LISU}

Pada sistem pengendapan yang terkait dengan proses tektonik, tidak memungkinkan untuk dilakukan identifikasi system tract yang dikontrol oleh perubahan muka laut. Pada tektonik aktif yang terjadi selama proses pengendapan, seperti pada fault-bounded setengah terban, sistem pengendapan didefinisikan sebagai tectonic system tract (Prosser, 1993). Tectonic system tract menjelaskan hubungan antara sistem pengendapan di area lisu dengan ekspresi seismik yang dibagi menjadi 4 tahap (Gambar 6), yaitu: rift initiation (S2), rift climax (S3), immediate post-rift (S4) dan late post-rift (S5).

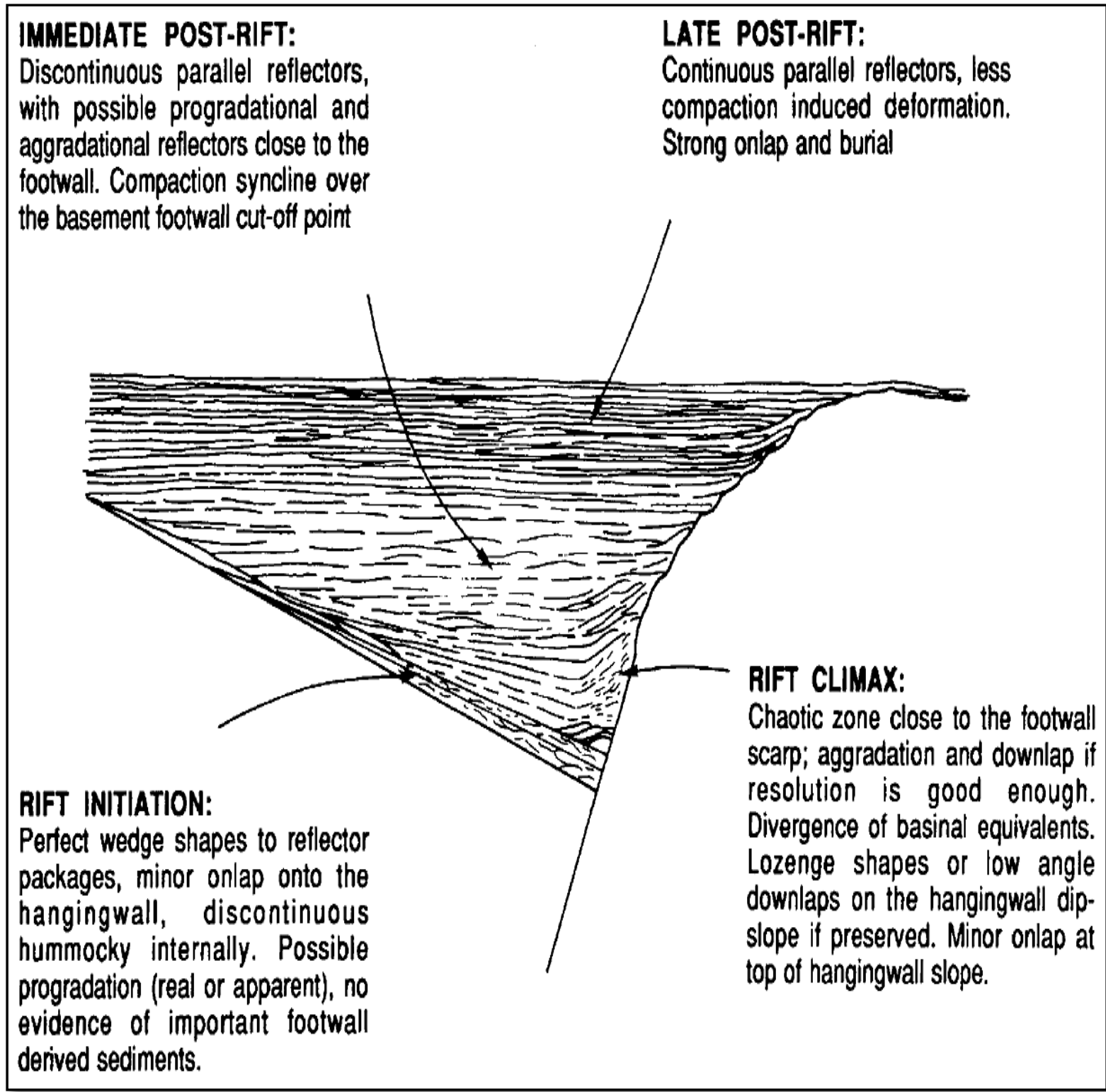

Gambar 6. Penampang ideal dengan karakteristik ekspresi seismik yang menunjukkan identifikasi tectonic system tract (Prosser, 1993).

Fase rift initiation (S2) merupakan respon awal terhadap pelisuan dengan laju sedimentasi lebih besar atau sama dengan subsiden. Pada fase rift climax (S3), peningkatan ruang akomodasi dan rendahnya laju sedimentasi cenderung membentuk topografi perselingan batupasir dengan batulempung. Pada fase immediate post-rift (S4), cekungan drainase telah terbentuk dan meluas akibat berakhirnya subsiden secara bertahap. Laju sedimentasi begitu juga ukuran butir meningkat. Fase late post-rift (S5) pada kondisi ideal merupakan 
degradasi area sumber secara berangsur yang menghasilkan sedimentasi dengan pola menghalus ke atas, kecuali bila terdapat faktor-faktor lain yang terlibat.

Empat horizon seismik dipetakan pada interval kedalaman lisu seismik 3D untuk kemudian digunakan sebagai horizon kunci analisis seismik geomorfologi dengan metoda sayatan strata (stratal slices). Horizon kunci dipilih berdasarkan horizon yang paling dapat diinterpretasi kemenerusannya dan mewakili interval paket-paket seismik yang akan diteliti. Keempat horizon tersebut adalah: horizon yang berdasarkan Sumur AA-1X merupakan serpih anggota Formasi Keras, horizon Top Lisu (Top Syn-rift), horizon yang berdasarkan Sumur AA-1X merupakan Formasi Lower Gabus dan horizon yang dinterpretasikan sebagai serpih yang merupakan anggota dari Formasi Benua (Gambar 5). Horizon Keras dan Benua menunjukkan amplitudo negatif yang kuat dan dapat diidentifikasi kemenerusannya di area seismik 3D. Horizon Lower Gabus memiliki karakter litologi berupa perselingan antara batupasir, serpih dan batulanau dengan dominasi litologi lempungan (argillaceous lithology) (Robertson Utama Indonesia, 1993; Murti dkk., 2015). Refleksi seismik horizon ini umumnya menunjukkan amplitudo bervariasi yang diskontinu.

Berdasarkan analisis geometri paket seismik dan analisis horizon serta fasies seismik, dapat diinterpretasikan bahwa stratigrafi endapan lisu dapat dibagi dalam empat fase tektonostratigrafi (tectonic system tract), yaitu: Lisu Awal (Early Rift), Lisu Tengah (Middle Rift), Lisu Akhir (Late Rift) dan Pasca-lisu Awal (Early Post-rift) (Gambar 7). Pembagian tektonostratigrafi di area lisu mempertimbangkan hubungan antara subsiden tektonik dengan laju sedimentasi, berbeda dengan pembagian tektonostratigrafi Cekungan Natuna Barat secara keseluruhan yang hanya mempertimbangkan kejadian tektonik regional.

\section{Lisu Awal (Early Rift)}

Interval fase ini dibatasi oleh Top Batuan Dasar (Basement) dan horizon Top Lisu Awal
(Top Early Rift). Hasil analisis karakter seismik menunjukkan bahwa batas atas dan bawah fase ini berupa reflektor seismik yang kontinu. Secara keseluruhan, fase ini berbentuk wedges, dengan konfigurasi internal: amplitudo rendah, reflektor diskontinu dan hummocky. Bentukan wedges (wedges-shape) mengindikasikan bahwa laju sedimentasi sejalan dengan subsiden. Interpretasi ini menjelaskan mengapa geometri ini lebih terbentuk daripada onlap reflektor terhadap strata di bawahnya (Prosser, 1993). Ekspresi seismik fase Lisu Awal (Early Rift) memiliki kemiripan dengan fase Rift Initiation (S2) Prosser (1993).

Peta atribut seismik CWT menunjukkan bentukan yang diinterpretasikan sebagai channel/meander yang berarah sejajar (posisi longitudinal) dengan orientasi sesar. Hal ini mengindikasikan bahwa tektonik mengontrol transportasi sedimen. Sedimentasi pada arah barat laut dan utara terlihat onlap terhadap batuan dasar. Lingkungan pengendapan fase Lisu Awal (Early Rift) dinterpretasikan sebagai fasies fluvial. Pada penampang seismik, fluvial pada fase Lisu Awal (Early Rift) umumnya menunjukkan reflektor hummocky. Reflektor negatif kontinu dan kuat yang berada di atas reflektor hummocky ini dinterpretasikan sebagai serpih yang merupakan anggota dari Formasi Benua.

\section{Lisu Tengah (Middle Rift)}

Interval fase ini dibatasi oleh horizon Top Lisu Awal (Top Early Rift) dan Top Lisu Tengah (Top Middle Rift). Analisis karakter seismik menunjukkan bahwa batas atas berupa reflektor yang diskontinu dan pada batas bawah interval fase ini terlihat onlap terhadap strata di bawahnya. Konfigurasi internal menunjukkan kemiringan divergen sub paralel dengan amplitudo bervariasi. Semakin mendekati footwall terlihat pola progradasi dengan reflektor sub paralel diskontinu. Ekspresi seismik fase Lisu Tengah (Middle Rift) memiliki kemiripan dengan fase Rift Climax (S3) Prosser (1993). 
Lingkungan pengendapan fase Lisu Tengah (Middle Rift) dinterpretasikan sebagai fasies lakustrin dangkal-dalam serta sebagian fasies deltaik fluvial. Secara umum pada peta stratal slice CWT menunjukkan reflektor seismik yang tidak berbentuk serta homogen yang mengindikasikan lingkungan lakustrin. Sedimentasi arah barat laut terlihat onlap terhadap batuan dasar. Fase ini diendapkan pada saat subsiden lebih cepat daripada laju sedimentasi. Pada kondisi maksimum subsiden terbentuk lingkungan danau.

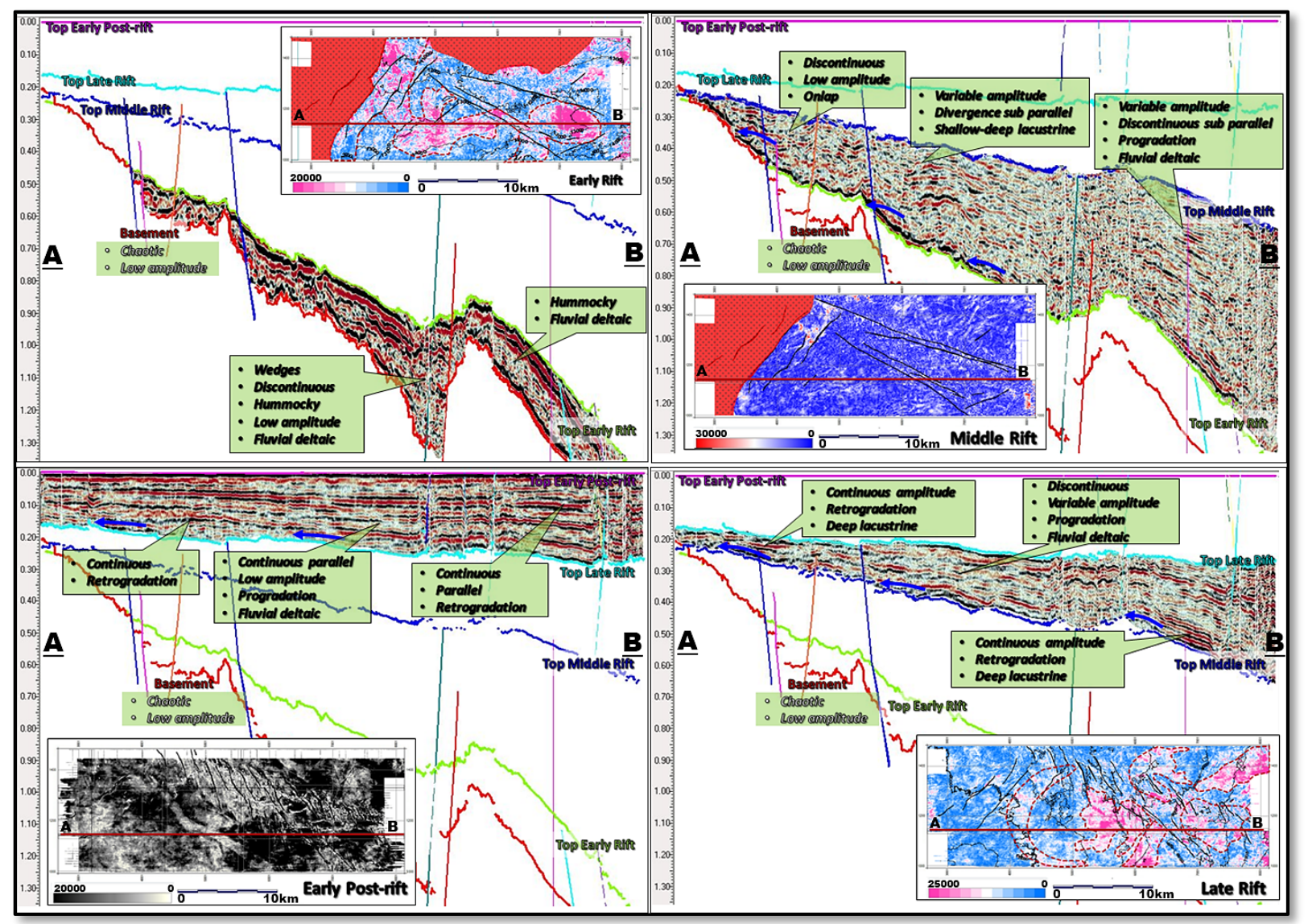

Gambar 7. Empat fase tektonostratigrafi dan peta atribut CWT pada endapan lisu, yaitu: Lisu Awal (Early Rift), Lisu Tengah (Middle Rift), Lisu Akhir (Late Rift) dan Pasca-lisu Awal (Early Post-rift). Penampang seismik A-B didatumkan pada Horizon Top Early Post-rift. Fase Early Rift dan Middle Rift terlihat onlap terhadap batuan dasar.

\section{Lisu Akhir (Late Rift)}

Interval fase ini dibatasi oleh horizon Top Lisu Tengah (Top Middle Rift) dan Top Lisu Akhir (Top Late Rift). Analisis karakter seismik menunjukkan batas bawah onlap terhadap strata di bawahnya. Secara suksesi vertikal, konfigurasi internal lebih kontinu, sub-paralel, amplitudo kuat dengan pola retrogradasi di bagian bawah berubah menjadi diskontinu, amplitudo bervariasi serta pola progradasi di bagian tengah sementara di bagian atas terlihat lagi konfigurasi fasies seismik retrogradasi dengan amplitudo kuat yang kontinu dan sub paralel.
Interval fase ini dinterpretasikan sebagai fasies deltaik fluvial di bagian tengah berubah menjadi fasies lakustrin dalam di atasnya. Fasies lakustrin dalam pada bagian bawah interval ini kemungkinan masih merupakan bagian dari fase Lisu Tengah (Middle Rift) yang terjadi pada saat subsiden maksimum yang merubah lingkungan pengendapan menjadi danau.

Peta atribut seismik CWT pada bagian atas interval fase ini menunjukkan bentukan yang diinterpretasikan sebagai channel deltaik. Lingkungan pengendapan fase Lisu Akhir (Late Rift) dinterpretasikan sebagai fasies 
fluvial yang berdekatan dengan fasies lakustrin atau lingkungan transisi. Fase ini diendapkan pada saat subsiden lebih lambat daripada laju sedimentasi. Ekspresi seismik fase Lisu Akhir (Late Rift) memiliki kemiripan dengan fase Immediate Post-rift (S4) Prosser (1993).

\section{Pasca-lisu Awal (Early Post-rift)}

Interval fase ini dibatasi oleh horizon Top Lisu Akhir (Top Late Rift) dan Top Pasca-lisu Awal (Top Early Post-rift). Analisis karakter seismik menunjukkan batas bawah onlap terhadap strata di bawahnya. Konfigurasi internal kontinu dengan pola retrogradasi di bagian bawah, sementara di atasnya terlihat kontinu, amplitudo rendah dengan pola progradasi yang mengindikasikan suksesi fasies lakustrin dalam secara berangsur berubah menjadi fasies deltaik fluvial. Di atas konfigurasi dengan pola progradasi terlihat konfigurasi internal kontinu dengan amplitudo kuat.

Lingkungan pengendapan fase Pasca-lisu Awal (Early Post-rift) secara umum dinterpretasikan sebagai dua fasies lakustrin yang mengapit fasies deltaik fluvial. Peta atribut seismik CWT pada fasies deltaik fluvial menunjukkan bentukan yang diinterpretasikan sebagai anastomosing channel dengan arah relatif tegak lurus terhadap orientasi struktur, menunjukkan bahwa transpor sedimen tidak lagi dikontrol oleh struktur (subsiden). Ekspresi seismik fase Pasca-lisu Awal (Early Post-rift) memiliki kemiripan dengan fase Late Post-rift (S5) Prosser (1993).

\section{SEISMIK-SIKUEN STRATIGRAFI ENDAPAN LISU}

Berdasarkan analisis sistem pengendapan, horizon seismik dan paket-paket geometri seismik di area penelitian, dijumpai batas-batas sikuen yang mengindikasikan ketidak selarasan (sequence boundary, SB), yang membagi area lisu menjadi 3 paket sikuen (Gambar 8), yaitu: Sikuen-1 (Interval SB0-SB1), Sikuen-2 (Interval SB1-SB2) dan Sikuen-3 (Interval SB2-SB3).

\section{Sikuen-1 (Interval SB0-SB1)}

Batas bawah Sikuen-1 (SB0) diidentifikasi berdasarkan Top Batuan Dasar (Basement) berumur Pra-Tersier, ditandai dengan reflektor seismik dengan amplitudo negatif kuat yang menerus tepat berada di atas seismik reflektor batuan dasar yang chaotic. Batas atas (SB1) ditandai dengan reflektor dengan amplitudo negatif kuat yang kontinu dan dijumpai di hampir seluruh area penelitian.

Di bagian timur penampang seismik terlihat horizon seismik yang onlap terhadap SB1. Diduga semakin ke arah bonding fault rift, yaitu pada arah timur-tenggara area penelitian, batas ketidakselarasan ini akan semakin terlihat. Fasies seismik paket ini secara umum menunjukkan amplitudo rendah, reflektor diskontinu dan hummocky, yang dinterpretasikan sebagai lingkungan dengan endapan fluvial. Secara keseluruhan menunjukkan geometri wedges.

\section{Sikuen-2 (Interval SB1-SB2)}

Batas atas Sikuen-2 (SB2) ditandai dengan reflektor yang diskontinu dan pada batas bawah paket ini (SB1) terlihat terminasi onlap terhadap strata di bawahnya. Fasies seismik paket ini menunjukkan kemiringan divergen sub paralel dengan amplitudo bervariasi. Semakin mendekati footwall terlihat pola progradasi dengan reflektor sub paralel diskontinu. Berdasarkan analisis sayatan strata dan fasies seismik, pada sikuen ini dapat didentifikasi 2 fasies pengendapan, yaitu lakustrin dangkal-dalam dan fluvial.

\section{Sikuen-3 (Interval SB2-SB3)}

Batas atas Sikuen-3 (SB3) ditandai dengan reflektor paralel yang diskontinu dan terminasi onlap horizon Top Syn-rift terhadap SB3. Pada batas bawah paket ini (SB2) terlihat terminasi onlap terhadap strata di bawahnya. Suksesi fasies seismik paket ini terlihat lebih kontinu, sub-paralel, amplitudo kuat dengan pola retrogradasi di bagian bawah berubah menjadi diskontinu, amplitudo bervariasi serta pola progradasi di bagian atas. Pada paket Sikuen-3 dijumpai 2 fasies pengendapan, yaitu fluvial dan lakustrin dalam yang mengindikasikan Sikuen-3 merupakan lingkungan transisi. 


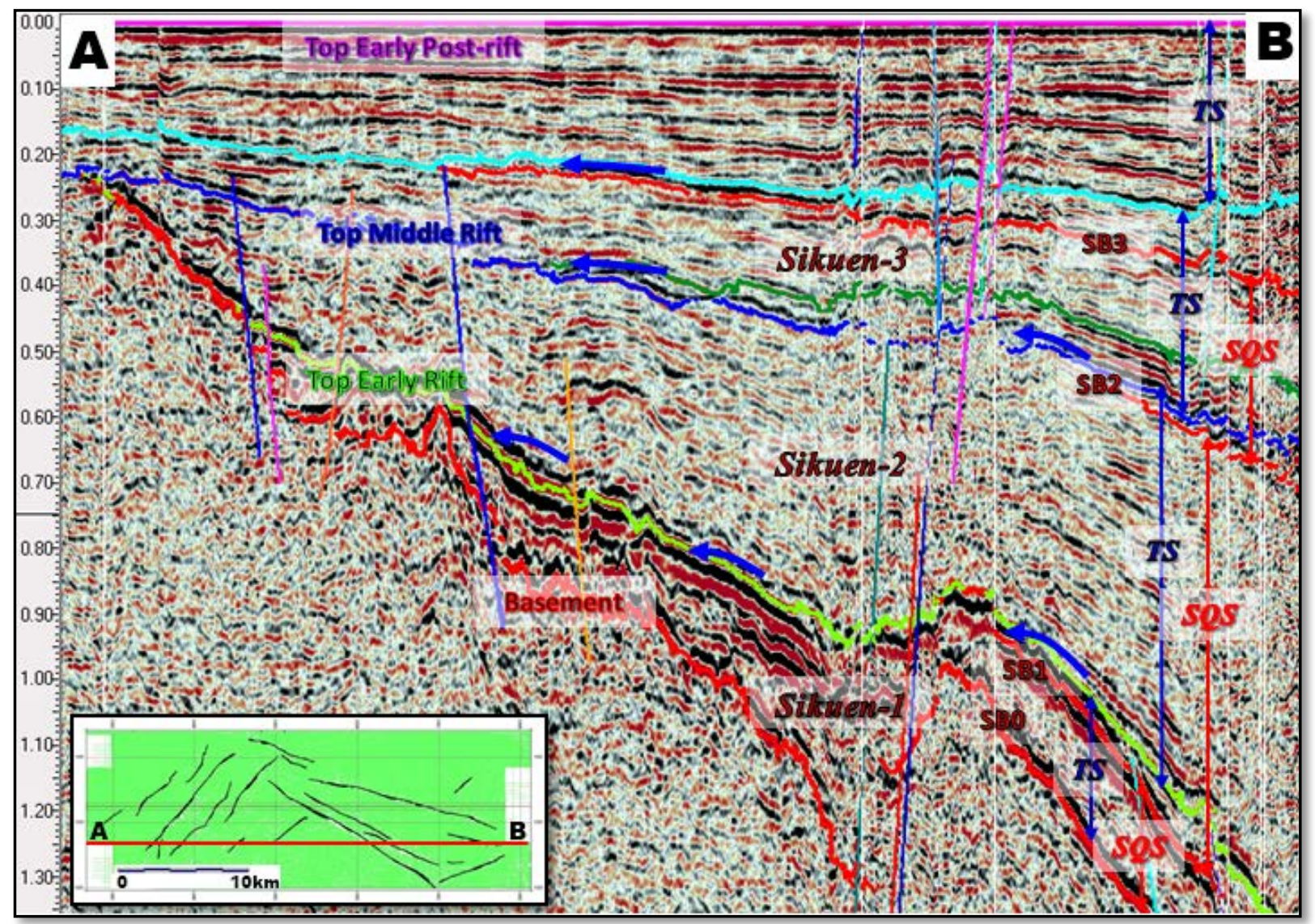

Gambar 8. Paket seismik-sikuen stratigrafi endapan lisu pada Penampang A-B, terdiri dari: Sikuen-1 (Interval SB0-SB1), Sikuen-2 (Interval SB1-SB2) dan Sikuen-3 (Interval SB2-SB3). Horizon Top Early Post-rift (ekuivalen dengan serpih anggota Formasi Keras) didatumkan untuk mendapatkan kondisi sistem pengendapan lisu. Horizon seismik berwarna merah merupakan sequence boundary (SB). SQS merupakan paket sikuen stratigrafi dan TS merupakan paket tektonostratigrafi.

\section{HASIL}

Secara umum, batas tektonostratigrafi dan batas sikuen stratigrafi di area penelitian relatif berimpit, namun semakin ke arah bonding fault-rift, perbedaan batas tersebut semakin terlihat (Gambar 8).

Batas tektonostratigrafi antara megasikuen lisu (syn-rift) dan pasca-lisu (post-rift), yaitu horizon Top Syn-rift, tidak berimpit dengan batas atas paket Sikuen-3 (SB3). Hal ini terjadi karena sikuen stratigrafi dan megasikuen kemungkinan dikontrol oleh proses tektonik lokal, seperti pada extensional tilted fault block. Selama proses pelisuan (rifting) pada fase akhir Sikuen-3, laju sedimentasi terlalu lambat untuk mengisi ruang akomodasi sehingga ruang akomodasi kemudian terisi oleh sedimentasi megasikuen pasca-lisu (post-rift) membentuk pola terminasi onlap pada top megasikuen lisu (top syn-rift) (William dan Dobb, 1993).

\section{KESIMPULAN}

Berdasarkan analisis seismik geomorfologi dengan sayatan strata, di daerah penelitian dijumpai tiga sistem pengendapan di area lisu, yaitu: deltaik fluvial, lakustrin dangkal dan lakustrin dalam. Metoda sayatan strata (stratal slice) merupakan metoda yang efektif untuk mendapatkan informasi stratigrafi yang konsisten dan gambaran seismik geomorfologi di area lisu secara lebih cepat.

Stratigrafi lisu di daerah penelitian sangat dikontrol oleh tektonik. Endapan lisu dapat dibagi dalam 4 fase tektonostratigrafi, yaitu: Lisu Awal (Early Rift), Lisu Tengah (Middle 
Rift), Lisu Akhir (Late Rift) dan Pasca-lisu Awal (Early Post-rift).

Lokasi daerah penelitian yang berada di tepi fleksur setengah terban dan endapan lisu yang merupakan lingkungan deltaik fluvial (fluvio-deltaic) hingga lakustrin dalam (deep lacustrine) menghasilkan sedimentasi dengan terminasi onlap terhadap strata di bawahnya. Endapan lisu di daerah penelitian dapat dibagi menjadi 3 paket seismik-sikuen stratigrafi, yaitu: Sikuen-1 (Interval SB0-SB1), Sikuen-2 (Interval SB1-SB2) dan Sikuen-3 (Interval SB2-SB3).

Secara umum, batas tektonostratigrafi dan batas sikuen stratigrafi di area penelitian relatif berimpit, namun semakin ke arah bonding fault-rift, perbedaan batas tersebut semakin terlihat. Paket sikuen stratigrafi (SQS) dibatasi oleh 2 batas sikuen (SB), sedangkan paket tektonostratigrafi (TS) dibatasi oleh 2 horizon seismik dengan geometri strata dan ekspresi seismik yang mengindikasikan evolusi pengendapan.

\section{UCAPAN TERIMA KASIH}

Terima kasih Penulis sampaikan kepada Conrad Petroleum (V) Ltd. atas bantuan data yang digunakan dalam penelitian ini.

\section{DAFTAR PUSTAKA}

BPPKA, Pertamina (1994): Petroleum geology of Indonesia basins.

Burton, D. dan Wood, L. (2010): Seismic geomorphology and tectonostratigraphic fill of half grabens West Natuna Basin Indonesia, AAPG Bulletin, 94(11), 1695-1712.

Continental Oil Company of Indonesia (1986): Well Forel-2 Final Geological Report (tidak dipublikasikan).

Murti, N., Minarwan dan Darman, H. (2015): The geology of Indonesia/Natuna, data diperoleh melalui situs internet: https://en.wikibooks.org/wiki/The_G eology_of_Indonesia/Natuna.

Diunduh pada 14 November 2015.

Posamentier, H., Davies, R. J., Cartwright, J. A., dan Wood, L. (2007): Seismic geomorphology-an
Geological Society London Special Publications, 277(1).

Prosser, S., (1993): Rift-related linked depositional systems and their seismic expression, Tectonics and Seismic Sequence Stratigraphy, Geological Society Special Publication, No. 71, 35-66.

Robertson Utama Indonesia, PT (1993): AA-1X Well palynostratigraphy and paleoenvironment, Lasmo Cumi-cumi LTD (tidak dipublikasikan).

Sinha, S., Routh, P., Anno, P., dan Castagna., J. (2005): Spectral decomposition with continuous wavelet transform, Geophysics, Vol. 70, No. 6, 19-25.

William, G. D. dan Dobb, A. (1993): Tectonics and seismic stratigraphy: an introduction, Geological Society London Special Publications, No. 71, 1-13. 